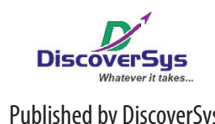

Published by DiscoverSys

\section{Association of supplementary feeding with stunting among children in Kintamani, Bangli, Bali Province}

\author{
Istiana Marfianti, ${ }^{1 *}$ I Made Ady Wirawan, ${ }^{1,2}$ I Wayan Weta ${ }^{1,3}$
}

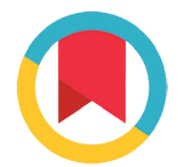

CrossMark

\section{ABSTRACT}

Background and purpose: The prevalence of stunting among under-five children in Indonesia and also in Bali is high. Studies on risk factors of stunting have been widely conducted in Indonesia, however association between stunting and diet pattern is still inconsistent. The aim of this study is to examine association of supplementary feeding pattern with stunting among children aged 1-3 years.

Methods: A case control study was conducted in Bangli District. A total of 48 cases and 48 controls were selected to participate in the study. Age and sex variables between cases and controls were matched. Cases and controls were selected using a systematic random sampling method from 26 health post registers in Kintamani I Public Health Centre between November and December 2016. Data were collected in March 2017 by interviewing the mother at the health post. Data were analysed using bivariate and multivariate analysis. A logictic regression was performed to calculate adjusted odd ratio (AOR).

Results: Cases and controls were comparable for age $(p=0.773)$, sex $(p=0.219)$, mother's education $(p=0.673)$ and history of infectious diseases $(p=0.584)$. Cases and controls differed in several variables: frequency, variability and type of supplementary feeding $(p=0.002,<0.001$ and $<0.001)$, family income $(p=0.038)$, poor personal hygiene $(p<0.001)$, environmental sanitation $(p=0.022)$ and access to clean water $(p<0.001)$. Our analysis showed that several variables were associated with stunting among children aged 1-3 years, which included lack of supplementary feeding variability $(A O R=12.45 ; 95 \% \mathrm{Cl}: 2.25-69.71)$, poor personal hygiene ( $A 0 \mathrm{R}=3.52 ; 95 \% \mathrm{Cl}: 1.03-12.03)$, and poor access to clean water $(A O R=6.49 ; 95 \% \mathrm{Cl}: 1.61-26.19)$. Other variables included supplementary feeding initiation, frequency of supplementary feeding, consistency or type of supplementary feeding, sex, and family income were not associated with stunting among children aged 1-3 years.

Conclusions: Variability of supplementary feeding, personal hygiene, and access to clean water were all associated with stunting among children aged $1-3$ years.

Keywords: case control, stunting, diet pattern, supplementary feeding

Cite This Article: Marfianti, I., Wirawan, I.M.A., Weta, I.W. 2017. Association of supplementary feeding with stunting among children in Kintamani, Bangli, Bali Province. Public Health and Preventive Medicine Archive 5(2): 95-100. D0I:10.15562/phpma.v5i2.21

Public Health Postgraduate Program Udayana University, ${ }^{2} S$ chool of Public Health Faculty of Medicine Udayana University University,

${ }^{3}$ Department of Community and Preventive Medicine Faculty of Medicine Udayana University

\section{*Correspondence to:}

Istiana Marfianti, Public Health

Postgraduate Program Udayana University

istiana.marfianti@yahoo.com

\section{INTRODUCTION}

As many as 154.8 million under-five children globally were stunted in 2016, where the highest prevalence was found in Asia with a total of 87 million stunted children. ${ }^{1}$ Indonesia is one among 17 countries that experiences double nutritional problems: malnourished (stunting and wasting) and overweight. ${ }^{2}$ The 2013 Basic Health Survey (Riskesdas) showed that the prevalence of stunting among under-five children in Indonesia was 37.2\%. ${ }^{3}$ The prevalence of stunting in Bali Province was 32.6\% while in Bangli District was $40 \%$ - ranked $2^{\text {nd }}$ after the Gianyar District. ${ }^{4}$ The nutrition surveillance conducted by Bangli District Health Office in 2015 revealed that the highest prevalence of stunting was found in working of Kintamani I Public Health Centre, with the prevalence of $44 \% .^{5}$

Studies on risk factors of stunting among children have been conducted in Indonesia, however association between diet patterns and stunting is still inconsistent. A study in Kendal-Central Java found that exclusive breastfeeding practice for six months and scores of supplementary feeding were not associated with stunting among children. ${ }^{6}$ Similar finding was reported in a study conducted in Pati, Central Java which found that exclusive breastfeeding, initiation of supplementary feeding, and score of supplementary feeding were not associated with stunting. ${ }^{7}$ A study in Mataram City, West Nusa Tenggara Province showed that inappropriate supplementary feeding practices increased the risk of stunting among children. ${ }^{8}$ A study in Nepal discovered that inappropriate sources of supplementary feeding against the WHO recommendation increased the risk of stunting among children. ${ }^{9}$ A study in Bangladesh also found that the lack of variability of supplementary feeding was associated with increased risk of stunting. ${ }^{10}$ The aim of our study is to examine association of supplementary feeding pattern with stunting among children aged 1-3 years.

\section{METHODS}

A case control study using matching by frequency for age and sex variables was conducted in Kintamani I Public Health Centre. Sample size was calculated at 
$95 \%$ confidence interval with power of $80 \%$. A total of 48 cases and 48 controls (case and control ratio is 1:1) were recruited to participate in our study. All cases (stunting) were selected using a systematic random sampling from 140 children aged 1-3 years who registered at 25 health posts in Kintamani I Public Health Centre between November and December 2016. By applying the same sampling method, controls were selected from 160 children (normal body height/length) aged 1-3 years from the same registers. Data were collected through interview at health posts. Respondents of the study were mother of the subjects who visited health post in March 2017. Written informed consent from the mother was obtained prior to data collection. Selected samples who did not attended the health post were replaced by other children who were listed in our sampling frame. Interviews were conducted by the researcher and assisted by two trained enumerators. Data about supplementary feeding consisted of feeding initiation, frequency, variability, type, concistency and exclusive breastfeeding. Other data collected included age and sex of the children, education of the mother, family income, personal hygiene, history of infections over the last three months, sanitation and access to clean water. In addition, data from the mother and child health book which included birth weight, immunization status and congenital diseases were collected.

Data were analysed using STATA SE 12.1. A logistic regression analysis was performed to calculate the adjusted odd ratio (AOR). The study protocol has been approved by the Human Research Ethics Committees of Faculty of Medicine Udayana University and Sanglah General Hospital Denpasar.

\section{RESULTS}

Table 1 presents characteristics of samples and respondents which included age and sex of the children, nutritional status, education, family income, personal hygiene, access to clean water and history of infections over the last three months. Sex and age variables between cases and controls were matched. Our analysis showed that cases and controls were comparable for age, sex, education level of the mother and history of infections over the last three months $(p>0.05)$. Several variables significantly differed between cases and control which included family income, personal hygiene, environmental sanitation, and access to clean water $(p<0.05)$. These variables were included in the multivariate analysis.

Table 2 depicts our bivariate analysis using chi-square test between dependent and independent variables. Several variables were found to have positive association with stunting among children which included: supplementary feeding initiation $(\mathrm{OR}=2.84 ; 95 \% \mathrm{CI}: 1.08-7.63)$, frequency of supplementary feeding (OR=4.23; 95\%CI: 1.51 $12.54)$, variability of supplementary feeding sources (OR=11.95; 95\%CI: 3.44-51.55) and type or concistency of supplementary feeding (OR=11.0; 95\%CI: 3.44-40.96).

Our multivariate analysis showed that risk factors of stunting among children aged 1-3 years were lack of variability of supplementary feeding sources (AOR=12.45; 95\%CI: 2.25-69.71), lack of access to clean water $(\mathrm{AOR}=6.49$; $95 \% \mathrm{CI}$ : 1.61 26.19) and poor personal hygiene $(\mathrm{AOR}=3.52$; 95\%CI: 1.03-12.03). Other variables included sex, family income, supplementary feeding initiation, frequency of supplementary feeding, type or consistency of supplementary feeding were not associated with stunting among children aged 1-3 years. These can be seen in Table 3 .

\section{DISCUSSION}

Our study found that the only significant risk factor related to supplementary feeding is the variability of the feeding sources. Further analysis showed that the association of stunting and supplementary feeding variation influenced by the difference of feeding sources by age among control group of the children. We found that the variability of supplementary feeding sources was significantly different between control group aged 4-6 months and $\geq 7$ months. The proportion of cases and controls who received ricebased supplementary feeding were 50\% respectively among children aged 4-6 months. However, among children aged $\geq 7$ months, cases mainly still received rice-based feeding (33.3\%) and some received ricebased and vegetables (31.3\%). Controls however received more varied sources of supplementary feeding - by combining rice, vegetables and animal protein $(60.4 \%)$.

Findings of our study is consistent with a study conducted in Bangladesh which showed that there was a significant association between food variability and stunting among children aged 6-11 months (OR=1.88; 95\%CI: 1.32-2.67); aged 12-23 months (OR=1.71; 95\%CI: $1.52-1.92)$, and aged 24-59 months (OR=1.15; 95\%CI: 1.11-1.19). ${ }^{10}$ The Bangladesh study involved six areas and food variability was measured by scoring technique. Respondents were asked how many days their children were provided each out of nine available food during the previous week..$^{10}$ Our study is also consistent with other study conducted in seven countries which found that food variability was associated with nutritional status among children using height or length over age indicator. ${ }^{11}$ Food variability may enable completion of essential nutrients among children. These essential nutrients are required to 
Table 1 Characteristics of samples and respondents

\begin{tabular}{|c|c|c|c|}
\hline Variables & $\begin{array}{c}\text { Case (48) } \\
\text { n (\%) }\end{array}$ & $\begin{array}{c}\text { Control (48) } \\
\text { n (\%) }\end{array}$ & p value \\
\hline Age of the children (month), (mean $\pm \mathrm{SD})^{*}$ & $25.37 \pm 6.91$ & $24.97 \pm 6.74$ & 0.773 \\
\hline \multicolumn{4}{|l|}{ Sex of the children: } \\
\hline Male & $29(60.4)$ & $23(47.9)$ & 0.219 \\
\hline Female & $19(39.6)$ & $25(52.1)$ & \\
\hline \multicolumn{4}{|l|}{ Nutritional status BW/Age: } \\
\hline Overweight & $1(2.1)$ & $0(0.0)$ & 0.008 \\
\hline Underweight & $12(25.0)$ & $2(4.2)$ & \\
\hline Normoweight & $35(72.9)$ & $46(95.8)$ & \\
\hline \multicolumn{4}{|l|}{ BW/Height: } \\
\hline Overweight & $12(25.0)$ & $2(4.2)$ & 0.014 \\
\hline Underweight & $1(2.1)$ & $2(4.2)$ & \\
\hline Normoweight & $35(72.9)$ & $44(91.6)$ & \\
\hline \multicolumn{4}{|l|}{ Mother's education: } \\
\hline$<$ Senior high graduate & $31(64.6)$ & $29(60.4)$ & 0.673 \\
\hline$\geq$ Senior high graduate & $17(35.4)$ & $19(39.6)$ & \\
\hline \multicolumn{4}{|l|}{ Family income } \\
\hline$<$ minimum regional wages & $33(68.7)$ & $23(47.9)$ & 0.038 \\
\hline$\geq$ minimum regional wages & $15(31.3)$ & $25(52.1)$ & \\
\hline \multicolumn{4}{|l|}{ Personal hygiene } \\
\hline Poor & $33(68.7)$ & $12(25.0)$ & $<0.001$ \\
\hline Good & $15(31.3)$ & $36(75.0)$ & \\
\hline \multicolumn{4}{|l|}{ Access to clean water } \\
\hline Poor & $30(62.5)$ & $6(12.5)$ & $<0.001$ \\
\hline Good & $18(37.5)$ & $42(87.5)$ & \\
\hline \multicolumn{4}{|l|}{ History of infections Diarrhoea } \\
\hline Yes & $9(18.8)$ & $7(14.6)$ & 0.584 \\
\hline No & $39(81.2)$ & $41(85.4)$ & \\
\hline \multicolumn{4}{|l|}{ Acute respiratory infections } \\
\hline Yes & $15(31.2)$ & $13(27.1)$ & 0.653 \\
\hline No & $33(68.8)$ & $35(72.9)$ & \\
\hline
\end{tabular}

support optimum growth and development of the children both physically and mentally. ${ }^{10}$

Supplementary feeding initiation was not associated with stunting among children. In our study, supplementary feeding initiation was classified as appropriate if it was initiated between the age of 4-6 months and inappropriate if it was initiated at the age either $<4$ months or $\geq 7$ months. This classification follows the guideline from European Society for Pediatric Gastrohepatology and Nutrion (ESPGHAN) which recommends that the appropriate age for supplementary feeding initiation is between 4 to 6 months. ${ }^{12}$ Our finding is not consistent with a study at Sanglah General Hospital Denpasar which found that babies who initiated supplementary feeding before the age of 4 months (early initiation) were 4.7 times more likely to experience growth failure during toodler period when compared to those who initiated supplementary feeding at the age of 4-6 months. This study also found that those who initiated supplementary feeding at the age of $>12$ months (late initiation) were 3.6 times more likely to experience growth failure when compared to those who initiated supplementary feeding at the age 4-6 months. ${ }^{13}$

Our study found that frequency of supplementary feeding was not associated with stunting among children. However, our study did not measure the amount of supplementary feeding provided to the children because it was difficult to obtain such information 
Table 2 Association between feeding patterns in the first year of life and stunting

\begin{tabular}{|c|c|c|c|c|c|}
\hline Variables & $\begin{array}{l}\text { Cases } \\
\text { n (\%) }\end{array}$ & $\begin{array}{c}\text { Control } \\
\text { n (\%) }\end{array}$ & Crude odd ratio & $95 \% \mathrm{Cl}$ & p value \\
\hline \multicolumn{6}{|l|}{ Exclusive breastfeeding } \\
\hline No & $38(79.2)$ & $41(85.4)$ & 0.42 & $0.18-2.11$ & 0.420 \\
\hline Yes & $10(20.8)$ & $7(14.6)$ & & & \\
\hline \multicolumn{6}{|c|}{ Supplementary feeding initiation } \\
\hline Inappropriate timing & $22(45.83)$ & $11(22.9)$ & 2.84 & $1.08-7.63$ & 0.020 \\
\hline On-time & $26(54.2$ & $37(77.1)$ & & & \\
\hline \multicolumn{6}{|c|}{$\begin{array}{l}\text { Frequency of supplementary } \\
\text { feeding }\end{array}$} \\
\hline Inappropriate & $40(83.3)$ & $26(54.2)$ & 4.23 & $1.51-12.54$ & 0.002 \\
\hline Appropriate & $8(16.7)$ & $22(45.8)$ & & & \\
\hline \multicolumn{6}{|c|}{$\begin{array}{l}\text { Variability of supplementary } \\
\text { feeding sources }\end{array}$} \\
\hline Inappropriate & $44(91.7)$ & $23(47.9)$ & 11.95 & $3.44-51.55$ & $<0.001$ \\
\hline Appropriate & $4(8.3)$ & $25(52.1)$ & & & \\
\hline \multicolumn{6}{|l|}{$\begin{array}{l}\text { Type or concistency of } \\
\text { supplementary feeding }\end{array}$} \\
\hline Inappropriate & $43(89.6)$ & $21(43.8)$ & 11.05 & $3.44-40.96$ & $<0.001$ \\
\hline Appropriate & $5(10.4)$ & $27(56.2)$ & & & \\
\hline
\end{tabular}

Table 3 Factors associated with stunting among children aged 1-3 years

\begin{tabular}{lccc}
\hline Variables & Adjusted odd ratio & $\mathbf{9 5 \%} \mathbf{C l}$ & p value \\
\hline Sex & 2.64 & $0.77-8.99$ & 0.119 \\
Family income & 1.14 & $0.32-4.11$ & 0.830 \\
Access to clean water & 6.49 & $1.61-26.19$ & 0.009 \\
Personal hygiene & 3.52 & $1.03-12.03$ & 0.044 \\
Supplementary feeding initiation & 0.35 & $0.07-1.70$ & 0.198 \\
Frequency of supplementary feeding & 1.54 & $0.29-8.15$ & 0.611 \\
Variability of supplementary feeding sources & 12.45 & $2.25-69.71$ & 0.004 \\
Type or concistency of supplementary feeding & 3.81 & $0.74-19.49$ & 0.107 \\
\hline
\end{tabular}

retrospectively from the mother. This may influence our finding related to association between stunting and frequency of supplementary feeding. A study in Ethiopia found that frequency and the amount of supplementary feeding provided to children were associated with stunting $(\mathrm{p}=0.03)$. Children who consumed food of $>600 \mathrm{ml} /$ day were more likely to have higher score on length/age when compared to those who consumed food of $<600 \mathrm{ml} /$ day. ${ }^{14}$

Our study revealed that consistency and type of supplementary feeding were not associated with stunting among children. Our finding is consistent with a study conducted in Sumatera which discovered that there was no significant association between nutritional status among children and concistency/ type of supplementary feeding $(\mathrm{OR}=0.8 ; 95 \% \mathrm{CI}$ : $0.3-2.3){ }^{15}$ Inappropriate consistency and type of supplementary feeding based on age of the children may influence physiological functions of kidney and digestive systems, which among babies are not completely mature. The extra workload on these immature systems might result in reduced absorption of nutrients. In a long term, this condition may lead to malnutrition among children. ${ }^{16}$

Other factors found to be associated with stunting is personal hygiene. Personal hygiene indicators used in our study included hand washing practices, water source used to wash plates and other dining facilities using, shower practices, the use of thong or shoes, and clean nail. Our bivariate analysis discovered that good personal hygiene practices reduced the likelihood of acquiring acute respiratory infections (OR=0.26; 95\%CI: 0.08-0.76), but were not associated with diarrhea $(\mathrm{OR}=2.97$; 
95\%CI: 0.84-11.84). Our finding is consistent with the 2007 Indonesia Basic Health Survey data which found that mothers who had children with normal nutritional status were more likely to perform good hand washing practices when compared to those who had stunted children $(\mathrm{p}<0.001) .{ }^{17}$ Another cross-sectional study conducted in Makasar revealed that personal hygiene was significantly associated with stunting among children $(\mathrm{p}<0.001) .^{18}$

We also found that access to clean water was associated with stunting among children. In our study, access to clean water was measured by assessing water used for drinking and cooking. Our descriptive analysis revealed that the sources of drinking and cooking water were differed between cases and controls. The majority of cases utilized rain water while controls mainly used piped water. Our interview showed that as many as $58.3 \%$ of cases did not optimally boil their water prior to consumption. Our findings are consistent with other study in Sumatera which found that families who have no access to clean water were 1.35 times more likely to have stunted children than those who have access to clean water (95\%CI: 1.05-1.72). ${ }^{19}$ Our analysis however showed that there was no significant association between access to clean water and acute upper respiratory track infections $(\mathrm{OR}=0.57$; 95\%CI: $0.19-1.60)$ and diarrhea (OR=1.37; 95\%CI: $0.38-4.62$ ). Our study found that there was no significant association between history of infections and personal hygiene or access to clean water. It can be explained that we only collected information about history of infections over the last three months whereas stunting is related to repeated infections over a long period of time..$^{20}$

Our study found that sex of the child was not associated with stunting. This finding is not consistent with a study conducted in Libya which documented that boys were 1.28 times more likely to experience stunting than girls (95\%CI: 1.05-1.55). ${ }^{21}$ Our study revealed that family income was not a risk factor of stunting among children. This is consistent with other study conducted in Makasar City which found that there was no significant correlation between family income and stunting among children $(\mathrm{p}=0.599) .{ }^{22}$

Our study indicates a need for improving variability of sources of supplementary feeding, especially within the first 12 months to reduce risks of stunting. Health education related to personal hygiene in particular hand washing is also essential in order to prevent recurrent infections which contribute to growth and development of the children.

Our study has several limitations. We relied on information provided by the mother on previous diet patterns which is vulnerable to recall bias. In addition, we did not collect information on the amount of supplementary feeding provided to the children. We did not convert nutritional status of stunted children based on their parent's height either. Therefore we are unable to calculate the genetic potential height of the children and also unable to differentiate genetic or nutritional associated stunting. Lastly, we only selected children who attended health posts between November and December 2016 - indicating that our study might be vulnerable to selection bias.

\section{CONCLUSION}

The lack of variability of supplementary feeding increases the risk of stunting among children. Varied sources of supplementary feeding contribute to fulfilment of essential nutrients required by children to achieve optimum growth and development. Other factors related to supplementary feeding are also important to prevent stunting which include initiation time, frequency, and concistency or type. Personal hygiene, particularly hand washing practices, and access to clean water are risk factors of stunting among children.

\section{ACKNOWLEDGEMENT}

We would like to thank Mr Agus Kawi Bawa, all respondents, and other parties who had supported and participated in our study. We would also like to extend our great gratitude to Prof. DN Wirawan, Dr I Gusti Lanang Sidiartha, and Dr Luh Seri Ani for all their advices and feedbacks throughout our study.

\section{REFERENCES}

1. UNICEF/WHO/World Bank. Levels and trends in child malnutrition key finding. Washington DC: UNICEF/ WHO/World Bank; 2017.

2. Global Nutrition. Action and accountability to accelerate the world's progress on nutrition. Washington DC: Global Nutrition; 2014.

3. Ministry of Health of Indonesia. Riset Kesehatan Dasar (RISKESDAS) 2013 [The 2013 Basic Health Survey]. Jakarta: Ministry of Health of Indonesi; 2013.

4. Ministry of Health of Indonesia. Riset Kesehatan Dasar dalam angka 2013 Propinsi Bali [The 2013 Basic Health Survey in Number for Bali Province]. Jakarta: Ministry of Health of Indonesi; 2013.

5. Bangli District Health Office. Laporan bulanan program gizi tahun 2015 [The 2015 nutrition program monthly report]. Bangli: Bangli District Health Office; 2015.

6. Meilyasari F, Isnawati M. Faktor risiko kejadian stunting pada balita usia 12 bulan di Desa Purwokerto Kecamatan Patebon, Kabupaten Kendal [Risk factors of stunting among children aged 12 months in Purwokerto Village Patebon Subdistrict Kendal District]. Journal of Nutrition College Semarang. 2014; 3: 26-32.

7. Anugraheni HS. Faktor risiko kejadian stunting pada anak usia 12-36 bulan di Kecamatan Pati, Kabupaten Pati [Risk factors of stunting among children aged 12-36 months in Pati Subdistrict] (Undergraduate thesis). Semarang: Faculty of Medicine, Diponegoro University; 2012. 
8. Najahah I, Adhi KT, Pinatih GI. Faktor risiko balita stunting usia 12-36 bulan di Puskesmas Dasan Agung, Mataram, Provinsi Nusa Tenggara Barat [Risk factors of stunting among children aged 12-36 months in Dasan Agung Community Health Centre, Mataram City, West Nusa Tenggara Province]. Public Health and Preventive Medicine Archive. 2013; 1(2).

9. Paudel R, Pradhan B, Rr W, et al. Risk factors for stunting among children : a community based case control study in Nepal. Kathmandu University Medical Journal. 2012; 39: $18-24$.

10. Rah J, Akhter N, Semba R, et al. Low dietary diversity is a predictor of child stunting in Rural Bangladesh. European Journal of Clinical Nutrition. 2010; 64: 1393-1398.

11. Arimond M, Ruel MT. Community and international nutrition dietary diversity is associated with child nutritional status: evidence from 11 demographic and health surveys. Journal Nutrition. 2004; 134: 2579-2585.

12. Fewtrell M, Bronsky J, Campoy C, et al. Complementary feeding: a position paper by the european society for pediatric gastroenterology, hepatology, and nutrition (ESPGHAN) Committe on Nutrition. Journal Pediatric Gastroenterology Nutrition. 2017; 64: 119-132.

13. Sidiartha IGL, Widianto R. Pengenalan makanan padat dini dan lambat pada bayi merupakan risiko gagal tumbuh pada masa toddler [Early and late initiation of solid food for babies as risk factor of growth failure among toddler period]. OJS. 2016; 51: 176-181.

14. Umeta $M$, West CE, Verhoef $H$, et al. Community and international nutrition factors associated with stunting in infants aged 5 - 11 months in the Dodota-Sire District, Rural Ethiopia 1. Journal Nutrition. 2003; 1064-1069.

15. Widyawati, Febry F, Destriatania S. Analisis pemberian MPASI dengan status gizi pada anak usia 12-24 bulan di wilayah kerja Puskesmas Lesung Batu, Empat Lawang [Supplementary feeding and nutritional status among children aged 12-24 months in Lesung Batu Community Health Centre catchment areas, Empat Lawang]. Jurnal Ilmu Kesehatan Masyarakat. 2016; 7(2).

16. Larasati. Hubungan antara praktik pemberian makanan pendamping ASI (MPASI) dan penyakit infeksi kaitannya dengan status gizi pada bayi umur 6-12 bulan [Association between supplementary feeding practices, infections, and nutritional status among children aged 6-12 months] [thesis]. Semarang: University of Semarang; 2011.
17. Aditianti. Faktor determinan stunting pada anak usia 24-59 bulan di Indonesia [Determinants of stunting among children aged 24-59 months in Indonesia] [thesis]. Bogor: Bogor Agricultural University; 2010.

18. Rahmayana, Ibrahim IA, Damayanti DS. Hubungan asupan zat gizi dan penyakit infeksi dengan kejadian stunting anak usia 24-59 bulan Di Posyandu Asoka II Kelurahan Barombong Kecamatan Tamalate Kota Makassar [Association between stunting, nutrient intake and infections among children aged 24-59 months in Asoka II Health Post Barombong Village, Tamalate Subdistrict, Makasar City]. Public Health Science Journal. 2014; 6: 424-436.

19. Oktarina Z, Sudiarti T. Faktor risiko stunting pada balita 24-59 bulan Di Sumatera [Risk factors of stunting among children aged 24-59 months in Sumatera]. Journal Gizi dan Pangan. 2014; 8: 175-180.

20. Checkley W, Epstein LD, Gilman RH, et al. Effects of acute diarrhea on linear growth in peruvian children. American Journal of Epidemiology. 2003; 157: 166-175.

21. Taguri A El, Betilmal I, Mahmud SM, et al. Risk factors for stunting among under-fives in Libya. Public Health Nutrition. 2017; 12: 1141-1149.

22. Ibrahim IA, Faramita R. Hubungan faktor sosial ekonomi keluarga dengan kejadian stunting anak usia 24 - 59 bulan di wilayah kerja Puskesmas Barombong Kota Makassar Tahun 2014 [Association between social economic and stunting among children aged 24-59 months in Barombong Community Health Centre catchment areas Makasar City year 2014]. Public Health Science Journal. 2015; 7: 63-75.

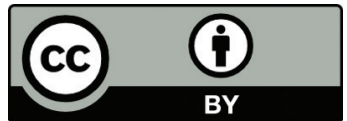

This work is licensed under a Creative Commons Attribution 